\title{
Guerra, cerco, fome e epidemias: memórias e experiências dos sertanejos do Contestado
}

Paulo Pinheiro Machado

Um morador de Taquaruçu, atual município de Fraiburgo, no planalto catarinense, que era criança na época da guerra, relata uma cena de bombardeio:

A força do governo também apertou muito no final. Teve um reduto, que começou a ser bombardeado por canhão, daí todos correram para a igreja, para se proteger. Logo um tiro de canhão atingiu a igreja, que estava lotada de crianças e mulheres, pegou fogo, quase todos morreram, isto eu vi. ${ }^{1}$

A imagem de uma igreja lotada de mulheres e crianças sendo incendiada é como um emblema de memória. Como afirma Frances Yates sobre os estudos mnemônicos de Francis Bacon, emblemas e imagens são resultados da fixação de emoções sensíveis, mais facilmente lembradas que princípios intelectuais ou outros relatos isentos de maior emoção. ${ }^{2}$ A força dessas memórias está associada a fortes impactos emocionais causados por diferentes imagens da guerra.

Por muito tempo existiu uma espécie de silêncio público sobre a Guerra do Contestado. Desde o final da guerra até a década de 1980, esse assunto não foi objeto da atenção pública, embora já houvesse uma farta produção de militares e acadêmicos sobre o tema. A partir dos anos 1980, como parte do processo de redemocratização do país, o conflito do Contestado passou, de distintas maneiras, a ser relembrado por movimentos sociais, órgãos de Estado e pesquisadores acadêmicos. No entanto, boa parte da população descendente dos seguidores do monge José Maria ainda apresenta uma memória de guerra fortemente impactada pela versão dos vencedores e pelos ressentimentos do olvido público. Um acontecimento não lembrado é quase algo não acontecido. A vergonha da derrota mistura-se com a sensação de irrelevância pública de uma experiência trágica presenciada. ${ }^{3}$ Por outro lado, o esquecimento pode ser apenas uma forma de readaptação à vida, como nos relata Alessandro Portelli. As pessoas não podem viver o tempo todo se lembrando de tudo. ${ }^{4}$

O estudo das memórias dos sobreviventes dos redutos rebeldes e seus descendentes ${ }^{5}$ envolvidos no movimento do Contestado (1912-1916) leva-nos a refletir sobre alguns aspectos marcantes e dolorosos das experiências dessas pessoas. É evidente que, devido à envergadura do movimento - que atingiu uma extensa região dos planaltos de Santa Catarina e do Paraná com mais de $22.000 \mathrm{~km}^{2}$ e acima de 150 mil habitantes - não há um só tipo predominante de memória das experiências da guerra. As pessoas foram atraídas aos redutos rebeldes, as chamadas "cidades santas", por diferentes razóes e dentro de distintos contextos regionais e de diferentes fases do conflito.

Entre os que se dirigiram a Taquaruçu, Caraguatá, Bom Sossego, Santa Maria, Perdizes, Pedra Branca, São Pedro e outros redutos e vilas dos seguidores do monge José Maria, havia um grupo inicial de seus devotos. Eles reelaboraram sua trajetória anterior, de práticas de curas até o combate do Irani, quando uma importante expedição do Regimento de Segurança do Paraná entrou em confronto com os caboclos, o que resultou na derrota da força policial; e, entre os sertanejos, na morte de José Maria. Um ano após esse combate os seguidores de José Maria voltaram a reunir-se em Taquaruçu, em torno da menina Teodora que relatava seus sonhos, afirmando que José Maria ordenava a seus seguidores que retornassem a Taquaruçu para seguir sua "Santa Religião".

A partir da formação da "Cidade Santa" de Taquaruçu, vários outros sertanejos passaram a agrupar-se no núcleo inicial. Havia um grande número de veteranos da Guerra Federalista (1893-1895), maragatos descontentes com o domínio dos republicanos, opositores políticos dos Coronéis da Guarda Nacional que governavam os municípios serranos de Santa Catarina. Taquaruçu e, depois, os novos 
redutos recebiam também muitos sertanejos expulsos de suas posses com a construção da estrada de ferro ao longo dos rios do Peixe, Iguaçu e Negro.

Até o mês de fevereiro de 1914, a guerra tinha sido um conjunto muito restrito de pequenos combates, fugas e escaramuças. Quando as tropas do exército cercam e bombardeiam o reduto de Taquaruçu, ocorre um massacre até então inédito na região do planalto. Estima-se em mais de duzentos habitantes os moradores de Taquaruçu, no momento do cerco e bombardeio por parte das forças do governo. Como os homens adultos tinham sido deslocados para a construção no novo reduto de Caraguatá, mais ao norte, a tropa oficial abriu fogo sobre um grande número de crianças, mulheres e velhos. Na memória dos sertanejos da região, a defesa de Taquaruçu foi comandada pela cabocla Francisca Roberta, chamada Chica Pelega, de quem não há qualquer outro registro contemporâneo. Como os militares temiam uma aproximação que possibilitasse uma luta corpo a corpo - preferida pelos caboclos -, trataram de postar suas forças em trincheira, cercando pelo alto o vale do Taquaruçu, e disparar balas de obuses e descargas de fuzis, por um dia, liquidando com a população irredutível. No dia seguinte ao bombardeio, a descrição dos poucos sobreviventes e dos próprios militares era aterradora. Mais de duzentas casas e uma Igreja foram destruídas pelos 175 tiros de granadas explosivas, tipo schrapnell. $\mathrm{Na}$ cidadela bombardeada, entre os escombros, encontravam-se pernas, cabeças decepadas, pedaços de corpos humanos e de animais. Um descendente dos chefes rebeldes, Valmor Carlin, afirma que a partir daí a guerra foi "de uma violência sem medida". ${ }^{6}$

No mês seguinte, os militares investem sobre o novo reduto de Caraguatá. As forças do Exército foram batidas pelos sertanejos. Atraídos para falsos atalhos, os militares se viram presos a espinheiros de inhapindaí, sendo encurralados para uma luta corporal com armas brancas, na qual os sertanejos levavam vantagem. Do alto das copas de imbuia e araucária, franco-atiradores caboclos dizimavam forças do governo com a precisão de suas carabinas. A violência do combate chegou ao hospital de sangue, sendo os militares feridos atacados com facões. No mês seguinte, uma nova expedição do Exército, chefiada pelo General Mesquita, identificou corpos de militares mortos em Caraguatá, espalhados ao longo da estrada que conduzia à Vila de São Sebastião da Boa Vista. Adolph Bading, imigrante alemão radicado em Canoinhas, tendo exercido o cargo de Juiz Substituto nesta vila, afirma que os pedaços dos corpos dos soldados do $54^{\circ}$ Batalhão de Caçadores, mortos em Caraguatá, foram retirados de suas sepulturas, "esquartejados e atirados aos porcos e cães, para serem devorados".

A intensificação da guerra aconteceu no segundo semestre de 1914, quando se inicia uma ofensiva rebelde generalizada, e os governos dos Estados do Paraná e de Santa Catarina pedem uma intervenção de maior peso do governo federal. Os rebeldes passaram a intensificar suas açôes para o planalto norte, em direção à Vila de Canoinhas e às estações da Estrada de Ferro São Paulo - Rio Grande. Para o sul, ocupam a Vila de Curitibanos e investem sobre a cidade de Lages. Nesse período, os revoltosos passam a recrutar toda a população do planalto para dirigir-se aos redutos, por bem ou por mal. Nas memórias de muitas famílias, era uma época de fuga do recrutamento das duas partes. Segundo Maria Conceição Correia, filha de um pequeno fazendeiro de Canoinhas, a atuação de sua mãe foi fundamental para a defesa de sua família:

Por aqui os jagunços viviam iludindo e enganando as pessoas para elas irem ao reduto. Alguns foram assim; foram convencidos. Outros foram levados à força. Eu lembro que morava aqui em Canoinhas, a cidade foi atacada, minha família teve que fugir de um sítio aqui perto, com a roupa do corpo. Fugimos para o Paraná e só voltamos no final da guerra. Isto aconteceu quando eu estava com meu pai e minha mãe debulhando milho em nosso sítio. Ouvimos um barulhão, eram os jagunços atirando e dando "vivas". Os jagunços queriam levar meu pai. Mas minha mãe deu gado e muito sal para os jagunços não levarem o meu pai. Quem não obedecesse à ordem dos piquetes dos jagunços, eles matavam. Foi minha mãe quem salvou nossa família, ela não deixou os jagunços levarem o meu pai, não deixou o pessoal do governo levar meu pai também. Naquele tempo o governo também pegava gente à força para virar soldado. ${ }^{8}$ 
Muitas famílias tiveram de fazer um difícil jogo para fugir da guerra. Alguns iam contra a sua vontade aos redutos, outros acabavam por aderir ao projeto rebelde e às suas ações. Mas, os que não eram atingidos pelos rebeldes, eram recrutados como soldados ou como vaqueanos (civis armados) pelas tropas oficiais, que careciam de gente que conhecesse o território e as formas locais de luta. $\mathrm{O}$ termo "jagunço", com todo o seu significado depreciativo, ligado ao banditismo, é utilizado indistintamente na região para a denominação dos rebeldes. Até mesmo descendentes de moradores dos redutos e de chefias rebeldes reproduzem essa linguagem desqualificadora, utilizando os termos "jagunço" e "fanático", como sinônimos dos seguidores de José Maria.

$\mathrm{Na}$ memória dos sobreviventes e seus descendentes, as razões do movimento sertanejo são frequentemente obscuras quando não reproduzem diretamente o discurso vencedor dos militares e dos políticos republicanos. Entre os fazendeiros e seus descendentes não há dúvida: o movimento sertanejo foi puro banditismo. O neto do coronel Antônio Carneiro, dos Campos de São João, afirma que:

A guerra foi assim, puro banditismo. Hoje tem muita gente contando outras coisas, dizendo que havia problemas de terras, que tinham sido tomadas pelos americanos, mas é tudo invenção. Naquela época havia terra de sobra para quem quisesse. Era tudo terreno devoluto. Os governos até facilitavam a legitimação das posses. Este sertão era muito grande, a população era pequena. ${ }^{9}$

A questão de terras é lembrada por Gilberto Kopecki, de Irineópolis, norte do planalto catarinense. Filho de Ana Júlia Kopecki, imigrante de origem polonesa que escrevia rezas para os sertanejos do reduto de Bonifácio Papudo, Gilberto lembra que a Brazil Lumber and Colonization Co., empresa norte-americana, subsidiária da Brazil Railway, encarregada da exploração da madeira e da colonização com imigrantes dos territórios marginais à estrada de ferro São Paulo-Rio Grande, usava de força, fraude e constrangimento político para expulsar os antigos moradores da região:

Em alguns lugares tiravam à força mesmo, com capangas. Em outras situações eles obrigavam o pessoal a assinar um papel em branco. Quem fez isto aqui foi o Nereu Ramos, que era advogado da Lumber. O Nereu, mesmo novo, tinha muita autoridade sobre as pessoas, era filho do Governador Vidal. Ele reuniu o pessoal dizendo que era para assinar em branco os papeis, que todos iam ter suas terras regularizadas. Que nada! As assinaturas serviam para as pessoas renunciarem ao direito de posse. Isto minha mãe viu pessoalmente, aconteceu mesmo. ${ }^{10}$

Para muitos, a Guerra começou como uma reação desmedida do Coronel Francisco Ferreira de Albuquerque - fazendeiro, rábula, comerciante e prefeito de Curitibanos - contra a presença do curandeiro José Maria na festa de Bom Jesus, em Taquaruçu. Alertada pelo coronel Albuquerque, uma força da polícia catarinense expulsou o monge José Maria e alguns de seus seguidores para a região do Irani, sob administração paranaense, em setembro de 1912. O combate que se seguiu com a força paranaense, no mês seguinte, e a consequente morte de José Maria, criou, para os governantes, a falsa sensação de que o movimento estava extinto.

Quando os sertanejos voltaram a reunir-se em Taquaruçu, um ano após o combate do Irani, não se tratava mais da festa de Bom Jesus, um povoado provisório em torno de um curandeiro, mas de um claro desafio ao coronel Albuquerque e às autoridades estaduais. Além do desafio político - pelo desrespeito às ordens do coronel - existia algo de novo entre os sertanejos.

Como resultado de um processo de reelaboração mística, a própria trajetória do curandeiro José Maria foi santificada, aproximando-o do monge João Maria, antigo andarilho que desde meados do século XIX trilhava os caminhos do planalto. ${ }^{11}$ A nova Taquaruçu seria uma comunidade criada para a prática da "Santa Religião"; deveria ser o local de vida de uma irmandade, onde todos trabalhariam e nada faltaria a ninguém.

Para Cipriano Fragoso, filho de um morador de Santa Maria - o maior reduto sertanejo, identificado pelo Capitão do Exército, Tertuliano Potiguara, como um conjunto de 5.500 casas e 24 igrejas -, os ser- 
tanejos pensavam em criar uma comunidade muito especial. Existe uma memória das relações comunitárias da irmandade; mas, a prática do saque, acusação dos inimigos, é confirmada pelos depoimentos dos antigos rebeldes:

Eles queriam uma revolução, queriam tomar conta do país, do Estado de Santa Catarina. Então, eles queriam que tudo fosse uma irmandade; tudo no comum. O que era produzido de criação e mantimento eles queriam comer junto, uma coisa assim. Mas ninguém trabalhava, então não tinham nada, tinham que buscar fora onde outros trabalhavam. ${ }^{12}$

Os problemas de abastecimento foram cruciais para o desenrolar do movimento. Embora muitos depoimentos confirmem a existência de criaçôes e lavouras trabalhadas pelos moradores dos redutos, a rapidez da guerra, o cerco militar e a crescente população desses povoados impedia uma autossuficiência alimentar e reclamava por outras soluções. Raulino Correa, que morou em vários redutos, explica como faziam para resolver o problema do abastecimento:

No reduto a gente voltava pros nossos sítios para colher o que fosse possível e pegar algum animal desgarrado. Depois, mais tarde o que funcionava mesmo eram os piquetes que iam pra cima das fazendas para arrebanhar gado. Me lembro que no começo as pessoas comiam muito nos redutos, mas depois foi diminuindo, diminuindo, até vir a fome mais braba. No fim, quando conseguiam uma ou duas rezes para matar pra todo aquele povo, as crianças cercavam o animal abatido e comiam até as tripas quentes. ${ }^{13}$

Com o aumento do cerco do exército aos redutos, a condição de arrebanhamento de gado alheio para abastecimento era cada vez mais difícil; então, segundo vários depoimentos, tudo o que se mexia podia ser comido. A memória da fome é particularmente impactante ao longo do período da guerra, já que, nessa região, embora a população de peões, agregados e posseiros fosse muito pobre, viviam, antes da guerra, num regime alimentar razoavelmente farto. Até mesmo no planalto, uma região típica de expansão da pecuária extensiva, havia grande número de roças de milho, feijão e mandioca. Os pobres também eram pequenos criadores, tanto de gado vacum como de suínos e aves. Durante a guerra, seus recursos foram dilapidados pela ação dos piquetes de vaqueanos e, muitas vezes, pelo próprio abandono de seus sítios de origem. Segundo Antônio França Pinto, como boa parte da população dos redutos lá estava contra a sua vontade, só a alguns era permitido sair para caçar ou para buscar víveres e gado. $\mathrm{O}$ clima de festa e fartura que existia inicialmente nesses povoados, foi sendo substituído pela escassez e pela desconfiança. Isso ocorreu na fase final do conflito, quando firmou-se a chefia de Adeodato (também chamado Leodato):

Com a bandeira na mão os jagunços começaram a tratar o Leodato como chefe, e ele foi se empolgando. O rapaz que pediu permissão para caçar queria mesmo era roubar gado alheio, era isto que os jagunços chamavam de caçar, e Leodato fez o mesmo que Chiquinho (antigo chefe) fazia, não deixou ir sozinho. Porque se fosse sozinho podia fugir. Os chefes só deixavam sair do reduto de dois ou mais; daí, um controlava o outro. Então, o rapaz disse que não tinha companheiro para sair junto, que já não tinham carne, que já estavam passando fome. Nisso, o Leodato, que não era comandante ainda, mas já estava na direção, puxou sua espada. Ele tinha uma espada que foi do D. Pedro II. Pois ele enfiou a espada no sujeito que queria sair. A espada atravessou a barriga e saiu pelas costas. Saía sangue para lá e para cá. O rapaz ferido ficou um tempo de pé e um negrinho com uns cinco anos, louco de fome, correu com uma caneca para pegar e beber o sangue que jorrava pela barriga e pelas costas do jagunço. No reduto tinha muita fome, comiam xaxim, comiam o diabo. ${ }^{14}$

A suposta espada de D. Pedro II é a referência que cria uma ligação dos sertanejos com a ideia de Monarquia, como Lei de Deus ou Lei do Céu, como defendiam. A chefia cruel do comandante Adeodato, que teve início em novembro de 1914, após a morte do chefe Chiquinho Alonso, é descrita como um conjunto de atos sanguinários, tanto por adversários, como por rebeldes. A descrição do menino se alimentando do sangue do sujeito atingido se soma a outras descrições de indivíduos que comiam 
vermes, formigas, e até carne humana para sobreviver. Em muitos outros depoimentos, a memória da fome aparece associada à tirania de Adeodato. Nestor Scholl, antigo homeopata que tratava a saúde da população da região do interior de Curitibanos e Fraiburgo, em entrevista concedida ao Padre Thomas Pieters, em 1973, afirma:

Muitos jagunços feridos vieram comigo no meu consultório e me contaram que os próprios jagunços mataram muitas pessoas; por lá de Liberata mataram duas famílias, sobraram três meninas, que foram no mato buscar pinhão para comer. Três famílias até foram matadas. Me contaram que o chefe dos jagunços matou muitas pessoas, o dia que ele não matou uma dúzia (...). Não houve homem que tinha coragem de matar ele, era Deodato, ele tinha doze capangas com facão. Eu sei de Joaquim Moreira, e um jagunço me contou, que ele mandou matar uma criança com a espada. De cada jagunço que matou cortou a orelha, fez um colar para o cavalo. Falei com muitos jagunços, me contaram como ocorreu, como foi. Foi uma coisa espantosa, eles morreram de fome, não tinham mais de que comer. Assim se terminavam os jagunços. ${ }^{15}$

Como Adeodato, na condição de comandante geral, chefiava o grupo de "Pares de França", provavelmente é essa a referência aos "doze capangas com facão". A crueldade aparece em estado puro, sem necessidade de razões. Os relatos orais sobre Adeodato, ainda hoje em curso, são muito semelhantes ao discurso de autovitimização dos sertanejos quando se apresentavam para a rendição final às tropas do Exército (na documentação do Exército, esses relatos são fartamente repetitivos nos Autos de Perguntas aos prisioneiros da Campanha do Contestado). Para vários testemunhos, com o comando de Adeodato, terminou a "santidade" e a "proteção" que existia dentro dos redutos. ${ }^{16}$ Milhares de pessoas declaram que viviam nos redutos contra a sua vontade; estavam lá unicamente por temor a Adeodato, quase sempre apresentado como um "demônio em pessoa". ${ }^{17}$ Mas a memória sobre os "Pares de França" parece ser mais generosa com esses indivíduos. Como muitos sobreviveram à guerra, deixaram suas impressões nas novas gerações. Sebastião Costa, morador da antiga Colônia Vieira, no planalto norte de Santa Catarina, conheceu, quando jovem, dois "Pares de França":

...aqui pela região viveu depois da guerra o Pedro Domingos, era Par de França, era um negão alto, forte, tinha bastante muque, trabalhou um tempo pro meu pai. O Pedro Domingos era homem de confiança do Leodato. Tinha também o Chicão, outro Par de França. Chicão não era negro, era caboclo de pele queimada. Chicão depois da guerra foi capataz do Severo de Almeida, um fazendeiro aqui do Tamanduá e trabalhou pro meu pai também, os dois eram homens de confiança de Leodato. Os Pares de França eram os mais corajosos e melhor lutadores. Agora, este pessoal era muito religioso também, tinham muita fé em Deus, eles sabiam coisas da Bíblia que nem os padres conheciam direito. Certa vez, este Pedro Domingos tinha um filho de 14 anos e queria que um padre que passou pela fazenda do Severo de Almeida batizasse o menino. O padre estava de má vontade, colocou um monte de problemas pra batizar o menino, daí o Pedro Domingos, que era analfabeto, disse pra ele: "Jesus Cristo disse: ide e batizais a todos. O senhor não segue a religião de Cristo?”. O padre ficou mudo e resolveu batizar o menino. Eles aprendiam estas coisas da Bíblia nos redutos. O Chicão e o Pedro contavam sobre muitos combates que eles participaram; uma vez contavam que na entrada do reduto de Santa Maria eles ficavam bem numa parte alta e em cima de umas forquilhas de imbuia, daquela altura, na galhada, eles acertavam os soldados que tentavam entrar no reduto. ${ }^{18}$

A rendição final permitiu a muitos rebeldes o retorno às atividades anteriores a guerra, como a de peões, capatazes e tropeiros. ${ }^{19}$ Porém, o trânsito para essa nova situação não era simples. A fase final da guerra foi de extrema violência, segundo Rosalina Watrin, descendente de imigrantes ucranianos e devota de São João Maria:

Em Santa Cecília do Rio Correntes, os fanáticos se aproximaram da casa de minha sogra, que estava sozinha com sua irmã Francisca. Logo elas tentaram fugir, mas notaram que estavam sendo observadas pelos fanáticos. Minha sogra se agarrou a um retrato de São João Maria, colocou um papel com uma oração no peito e não foi molestada pelos fanáticos. A Francisca saiu correndo de costas tão rápido que eles pensaram que fosse homem e atiraram. Eles evitavam atirar em mulheres e crianças. Só atiravam em homens, eles pensaram que a Francisca era homem. Ela foi acertada com uma bala nos quartos, caiu no chão e foi arrastada 
mato a dentro, bem longe, pela minha sogra. Minha sogra dava água pra irmã aos punhados. Daí nisso veio um velhinho, do outro lado do mato, também estava fugindo dos fanáticos, disse chamar-se Fernando ou Firmino, disse que conhecia o pai delas e que ia tirar elas do mato. $\mathrm{O}$ velhinho disse que ia bombear [espionar] pelo mato, contornar os jagunços e avisar o pai delas para ir buscar. Daí um Capitão do exército foi achado pelo velhinho e ele mandou um pequeno piquete de cavalaria para buscar as duas mulheres. Pois o piquete do exército passou bem na frente de um bando enorme de jagunços, armados até os dentes de facôes, revólveres, winchesters, que deixaram os soldados resgatar as mulheres. As duas passaram com os soldados pelo meio dos jagunços e eles não fizeram nada, elas passaram com muito medo, podiam ser trucidadas ali. No que chegaram ao acampamento do exército, onde tinha uma trincheira, mais adiante, o comandante ficou indignado com o fato dos jagunços terem atirado na Francisca e ele disse e ordenou à sua tropa que todos os jagunços deviam ser liquidados. Ele disse que os jagunços não tinham lei, que faziam malvadeza com as mulheres. Foi bala pra tudo que é canto, juntou exército, polícia, vaqueanos, tudo, foram pra cima dos jagunços e acabaram com eles. Chegaram a empilhar os corpos dos fanáticos pra atear fogo. Matar tudo, tudo, homens, mulheres, crianças também. A ordem do governo era matar tudo. As crianças eles erguiam, jogavam pra cima e espetavam com uma espada empinada. ${ }^{20}$

Como recurso recorrente, fenômenos de massacre são explicados a partir de ocorrências ocasionais, acidentes fortuitos ou mal-entendidos. Para Rosalina, o massacre dos "fanáticos" pelas tropas oficiais se explica pelo disparo equivocado que os rebeldes fizeram em uma mulher. Mas as forças oficiais aqui relatadas são muito mais que o Exército. Além da polícia, há os grupos de vaqueanos civis. Normalmente eram fazendeiros, oficiais da Guarda Nacional, que colocavam seus peóes em armas para servir de guias às tropas do exército e para "limpar" determinados territórios da presença de rebeldes, no início dos conflitos.

A importância desses grupos ligados ao poder local - que muitas vezes recrutavam seu efetivo entre rebeldes rendidos (como nos casos notórios de Henrique Wolland, o Alemãozinho, e Gregório de Lima) - foi crescendo no decorrer da guerra. Os vaqueanos atuaram com muita intensidade ao final do conflito, conhecido como a fase do açougue. Segundo João Melo, que foi menino de recados do chefe Adeodato, "na guerra até não morreu muita gente, mas depois da guerra tinha muita gente sendo paga para matar caboclos. Muitos correram pra toda parte para se esconder. Muita gente foi morta a aprisionada depois da guerra". ${ }^{21}$ Quando o último reduto é ocupado pelas tropas do chefe vaqueano, Lau Fernandes, em dezembro de 1915, há um lento processo de fuga e apresentação dos rebeldes às autoridades militares nos meses seguintes. Avelino Correa, filho de tropeiro que abastecia as tropas do Exército, informa que, quando um grande grupo de rebeldes se apresentou às forças oficiais, alguns ficaram aos cuidados de líderes vaqueanos, como Firmino Chaleira:

Logo depois um grande número de jagunços se apresentou ao exército, se rendeu, porque também vinha exército de Curitiba, de outros lados. Eu vi o estado em que eles passaram por aqui. Eram puxados pelo Firmino Chaleira - ou Firmino Brito; era chamado de Chaleira porque tinha um nariz "deste tamanho" [faz um gesto amplo] - que trabalhava pra força. Dizem que ele levava muito bandido para "ver abelha no mato"; ele levava lá e matava mesmo. ${ }^{22}$

Chefes vaqueanos, conhecidos por sua violência com os prisioneiros, eram Pedro Leão de Carvalho, ou Pedro Ruivo, que agia na região de Canoinhas, respondendo a processo por ter executado mais de cem prisioneiros retirados da cadeia da Vila e degolados nas margens do Rio Iguaçu, e Coletti, que liderava um grupo de vaqueanos atuando na região do Rio Correntes, próxima à Vila de Curitibanos. ${ }^{23}$ Ayurê Tavares, filho do chefe rebelde Antônio Tavares de Souza Júnior, que, apesar de ter aderido ao movimento rebelde tinha fortes ligaçóes com o situacionista Partido Republicano Catarinense, conta que quando o seu reduto foi bombardeado pelas forças do Tenente-Coronel Taurino de Resende, seu pai:

fugiu com uns vinte, pegaram o mato, alguns morreram, porque não resistiram, eles nem podiam dar um tiro numa caça senão chamava a atenção. Tinham algum dinheiro, foram se virando pelo caminho. Escreveram uma carta anônima para meu avô avisando que o Tavares deveria se manter escondido porque ele estava sendo caçado. O clima no final da guerra era de execução. ${ }^{24}$ 
Um testemunho da época (setembro de 1915), escrito pelo Juiz Adolph Bading, de Canoinhas, explica que, após a destruição do reduto de Santa Maria, em abril de 1915, a maioria das unidades do exército abandonou a região, com o general Setembrino declarando terminada a sua missão. No entanto, as autoridades militares já sabiam, em maio, que dois redutos remanescentes formaram-se com os sobreviventes de Santa Maria: Pedra Branca e Timbó. ${ }^{25}$ Para outro juiz de Canoinhas, dr. Miletto, o exército não era muito eficaz no combate aos caboclos, defendendo que "a luta, para ser profícua ao restabelecimento da ordem sem grandes ônus ao país, tem que ser de caboclos contra caboclos". ${ }^{26} \mathrm{O}$ governo federal, a pedido das autoridades estaduais, distribuiu armas entre os civis, e apoiou a ação dos vaqueanos para erradicar finalmente com os rebeldes no planalto norte de Santa Catarina:

Mesmo assim os casos de mortes e assaltos novamente assustavam a população, e quase todos deixavam suas casas saindo da mata para a Vila [de Canoinhas]. Assim, desde o início de agosto [de 1915], toda a região entre a vila e [o rio] Paciência ficou despovoada. Em seguida o governo do estado decidiu exigir do governo federal armas para a população civil, as quais foram concedidas e enviadas. Então se armou um piquete com pessoas civis para acabar com os jagunços. Estas operações ainda não estão terminadas, porém se espera, que estas sejam coroadas de êxito, e que daí finalmente o conjunto do movimento de revolta, que prejudicou imensamente a terra, seja de todo reprimido. ${ }^{27}$

Muitas vezes, a rendição a chefias vaqueanas tinha de ser muito negociada e realizada com pessoas de confiança, devido aos perigos corridos. Sebastião Costa relata a atuação de seus parentes na busca de rebeldes escondidos no mato e no cuidado com que isto devia ser realizado:

Muita gente ficou escondida no mato bastante tempo; queriam ter segurança para se apresentar às forças do governo. Por aqui, um tio meu, o Júlio Costa, tinha trabalhado pras forças do governo, mas conhecia muitos jagunços que estavam no reduto. Ele fazia várias viagens ao Timbó e ao Tamanduá e trazia aos poucos as famílias que iam se apresentando. Aquele pessoal chegava miserável, muitos nem roupas tinham. Meu pai também, na época tinha 18 anos, ele trouxe muita gente do mato que queria se apresentar e estava com medo. Depois, este pessoal dos redutos ficou por aqui mesmo, voltaram cada um para as suas terrinhas. ${ }^{28}$

Raulino Correa, que viveu nos redutos até o final, conta como foi a rendição de sua família e o temor de cair em mãos erradas:

Tava muito difícil no reduto. Passamos muita fome. A fraqueza era grande. Quando a guerra terminou, conseguimos fugir para um sítio de um amigo de meu pai. Ele nos deu água com mel. Um copo para cada um. Me senti nascendo de novo, de tão fraco que estava. Neste sítio do amigo do meu pai, um tal de Domingos Beja, muitas famílias que fugiram do último reduto estavam escondidas. Naquela noite o meu pai disse ao Domingos que no dia seguinte ia se apresentar ao Goethen, em Santa Cecília: o filho do velho Goethen, que estava com o pessoal do governo. Meu pai foi pra lá com dois piás e um irmão da minha mãe, que era um homem alto e sujeito muito prosa, sabia se entender com o pessoal do governo. No fim da tarde, meu pai retornou com eles. Vinham com muita comida, café, tudo. Daí foi só ficar gritando pelo mato por perto que as pessoas iam se apresentando. Depois voltamos para o nosso antigo sítio. Era uma tristeza, tinham levado tudo. Foi o pessoal do governo quem roubou tudo. O Coletti, de Santa Cecília, que era vaqueano do governo, roubou muito sítio de jagunço e matou muitas pessoas que já tinham se entregado. Mas o Coletti também perdeu muita gente de sua família. Os filhos dele acabaram se matando. Por conta dos banditismos que o Coletti andou fazendo ele chegou a sofrer de uma dor no peito que os médicos nunca descobriram. Este pagou aqui pelo que fez. ${ }^{29}$

A memória presente nas entrevistas dos sobreviventes do conflito e seus descendentes - com muita frequência - "embaralha” épocas e regiōes distintas e ressignifica estratégias de legitimação de determinados comportamentos, Contudo, esses depoimentos são documentos legítimos que precisam ser estudados dentro do seu contexto formativo. Constituem-se em fontes fundamentais para o estudo da vida dentro dos redutos, para a análise dos processos de rendição, para a avaliação da atuação dos vaqueanos civis. Processos, todos eles, muito pobremente documentados pelas fontes oficiais. 


\section{Notas}

${ }^{1}$ Entrevista com João Maria Palhano, MACHADO, Paulo Pinheiro. Um estudo sobre as origens sociais e a formação politica das lideranças sertanejas do Contestado, 1912-1916. Tese de doutorado apresentada ao Programa de Pós-Graduação em História da UNICAMP. Campinas, 2001. Anexos.

${ }^{2}$ YATES, Frances A. A arte da memória. Tradução de Flávia Bancher. Campinas: UNICAMP, 2007, p. 461.

${ }^{3}$ Interessante reflexão sobre a memória de guerra e esquecimento encontramos no estudo sobre a Guerra Colonial Portuguesa (1961-1974) em CAMPOS, Ângela. Vivendo com a guerra: uma entrevista com o Sr. A. Fortuna. Estudos Históricos, Rio de Janeiro, v. 22, n. 43, jan.-jun. 2009, p. 45-64.

${ }^{4}$ PORTELLI, Alessandro. A Bomba de Turim: a formação da memória no pós-guerra. Revista História Oral, n. 9, São Paulo, 2006.

${ }^{5} \mathrm{O}$ presente estudo foi originalmente escrito para a intervenção do autor na mesa-redonda "Margens do rural", no âmbito do Simpósio Internacional História e Margem, promovido pelo Programa de Pós-graduação em História Social da Universidade Federal do Rio de Janeiro (UFRJ), entre 18 e 20 de outubro de 2010.

${ }^{6}$ Entrevista com Valmor Carlin do Prado. MACHADO, Paulo Pinheiro. Op. cit. Anexos.

${ }^{7}$ BADING, Adolph. Die Fanatikerbewegung in Contestado (Paraná und Santa Catarina). In: Almanaque Alemão. Canoinhas: s/ed. 1916.

${ }^{8}$ Entrevista com Maria Conceição Correia. MACHADO, Paulo Pinheiro. Op. cit. Anexos.

${ }^{9}$ Entrevista com Dario Carneiro. MACHADO, Paulo Pinheiro. Op. cit. Anexos.

${ }^{10}$ Entrevista com Gilberto Kopecki. MACHADO, Paulo Pinheiro. Op. cit. Anexos.

${ }^{11}$ Estudos mais detidos sobre o processo de reelaboração mística dos sertanejos, ocorrido entre o combate do Irani e a formação do segundo reduto de Taquaruçu encontramos em VINHAS DE QUEIROZ, M. Messianismo e conflito social: a Guerra Sertaneja do Contestado. Rio de Janeiro: Civilização Brasileira, 1966 e em MONTEIRO, Duglas Teixeira. Os errantes do Novo Século. São Paulo: Duas Cidades, 1974. Importante testemunho sobre estas transformações encontramos em LEMOS, Alfredo de Oliveira. A história dos fanáticos em Santa Catarina e parte de minha vida naqueles tempos. Passo Fundo: Beltier, s/d.

${ }^{12}$ Entrevista com Cipriano Cardoso. MACHADO, Paulo Pinheiro. Op. cit. Anexos.

${ }^{13}$ Entrevista com Raulino Correa. MACHADO, Paulo Pinheiro. Op. cit. Anexos.

${ }^{14}$ Entrevista com Antônio França Pinto. MACHADO, Paulo Pinheiro. Op. cit. Anexos.

${ }^{15}$ Entrevista de Nelson Scholl a Thomas Pieters em 17/11/1973. Mimeo.

${ }^{16}$ Essa mudança fica muito explícita nas entrevistas de Porfírio Alonso (irmão do chefe Chiquinho Alondo) para MONTEIRO, Duglas Teixeira. Op. cit., e na entrevista de Elias Ribeiro em MACHADO, Paulo Pinheiro. Op. cit. Anexos.

${ }^{17}$ Sobre a demonização de Adeodato, cf. MACHADO, Paulo Pinheiro. Op. cit. Capítulo 5.

${ }^{18}$ Entrevista com Sebastião Costa. MACHADO, Paulo Pinheiro. Op. cit. Anexos.

${ }^{19}$ Importante estudo sobre a origem e a atuação dos "Pares de França" ou "Pares de São Sebastião" no movimento do Contestado, encontramos em ESPIG, Márcia Janete. A presença da gesta Carolíngea no movimento do Contestado. Canoas: Ed. da ULBRA, 2004 e em FELIPE, Euclides José. O último jagunço: o folclore na história da Guerra do Contestado. Curitibanos: Ed. UnC, 1995.

${ }^{20}$ Entrevista com Rosalina Watrin. MACHADO, Paulo Pinheiro. Op. cit. Anexos.

${ }^{21}$ Entrevista com João Melo. MACHADO, Paulo Pinheiro. Op. cit. Anexos.

${ }^{22}$ Entrevista com Avelino Correa. MACHADO, Paulo Pinheiro. Op. cit. Anexos.

${ }^{23}$ Processo-crime por assassinato, réu: Pedro Leão de Carvalho, Comarca de Canoinhas, 1918. Apesar da atividade do Promotor em juntar provas aceitas pelo Juiz, o réu foi absolvido 3 vezes pelo júri.

${ }^{24}$ Entrevista com Ayurê Tavares. MACHADO, Paulo Pinheiro. Op. cit. Anexos.

${ }^{25}$ Importante estudo sobre a atuação dos vaqueanos civis encontramos em RODRIGUES, Rogério Rosa. Veredas de um grande sertão: a Guerra do Contestado e a modernização do Exército brasileiro na Primeira República. Tese de Doutorado apresentada no Programa de Pós-Graduação em História da UFRJ, Rio de Janeiro, 2008.

${ }^{26}$ Jornal O Lageano, Lages, 26/06/1915.

${ }^{27}$ BADING, Adolph. Op. cit., p. 45.

${ }^{28}$ Entrevista com Sebastião Costa. MACHADO, Paulo Pinheiro. Op. cit. Anexos.

${ }^{29}$ Entrevista com Raulino Correa. MACHADO, Paulo Pinheiro. Op. cit. Anexos. 


\section{Referências}

BADING, Adolph. Die Fanatikerbewegung in Contestado (Paraná und Santa Catarina). In: Almanaque Alemão. Canoinhas: s/ed. 1916

CAMPOS, Ângela. Vivendo com a guerra: uma entrevista com o Sr. A. Fortuna. Estudos Históricos, Rio de Janeiro, v. 22, n. 43, jan-jun 2009, p. 45-64.

ESPIG, Márcia Janete. A presença da gesta Carolíngea no movimento do Contestado. Canoas: Ed. da ULBRA, 2004. FELIPE, Euclides José. O último jagunço: o folclore na história da Guerra do Contestado. Curitibanos: Ed. UnC, 1995. LEMOS, Alfredo de Oliveira. A história dos fanáticos em Santa Catarina e parte de minha vida naqueles tempos. Passo Fundo: Beltier, s/d.

MACHADO, Paulo Pinheiro. Um estudo sobre as origens sociais e a formação política das lideranças sertanejas do Contestado, 1912-1916. Tese de doutorado apresentada ao Programa de Pós-Graduação em História da UNICAMP. Campinas, 2001.

MONTEIRO, Duglas Teixeira. Os errantes do Novo Século. São Paulo: Duas Cidades, 1974.

PORTELLI, Alessandro. A Bomba de Turim: a formação da memória no pós-guerra. Revista História Oral, n. 9, São Paulo, 2006.

RODRIGUES, Rogério Rosa. Veredas de um grande sertão: a Guerra do Contestado e a modernização do Exército brasileiro na Primeira República. Tese de Doutorado apresentada no Programa de Pós-Graduação em História da UFRJ, Rio de Janeiro, 2008.

VINHAS DE QUEIROZ, M. Messianismo e conflito social: a Guerra Sertaneja do Contestado. Rio de Janeiro: Civilização Brasileira, 1966.

YATES, Frances A. A arte da memória. Tradução de Flávia Bancher. Campinas: UNICAMP, 2007.

\section{RESUMO}

Este artigo procura analisar o significado de determinadas ocorrências na Guerra do Contestado (1912-1916) compartilhadas pela memória da população serrana de Santa Catarina. As razóes do movimento rebelde, a questão de terras, o cerco aos redutos rebeldes, a fome e a violência, são fenômenos estudados em entrevistas de sobreviventes e seus descendentes. Palavras-chave: memória, fome, Guerra do Contestado, violência, camponeses.

\section{ABSTRACT}

This paper attempts to analyze the meaning of certain occurrences in the Contestado War (1912-1916) that are shared by the memory of the inhabitants of the mountain range of Santa Catarina. The reasons of the rebel movement, the agrarian problems, the siege of the rebel villages, hungry and epidemics, are phenomena studied in interviews of survivors and their descendants.

Keywords: memory, hungry, Contestado War, violence, peasants. 